\title{
Tax Incentives of Demand for Insurance Market Services in Russia
}

\author{
${ }^{1}$ M. E. Orlova, F. F. Adigamova, ${ }^{2}$ Larisa S. Kirillova, ${ }^{3}$ Alisher R. Khodzhiev \\ 1,2,3 Kazan Federal University, 18 Kremlyovskaya str., Kazan, 420008
}

Received: 21st October 2017 Accepted: 16th November 2017, Published: 31st December 2017

\begin{abstract}
The article is devoted to the tax methods of stimulation of organization's and individual's financial initiatives in the field of insurance in Russia. The article describes the main problems and factors of insurance market development in Russia, summarizes the scientist's points of view of such factors. It was determined that tax methods of regulation can influence the interaction of participants of economic relations. In article specified the types of preferences offered by the Russian legislation, organizations and individuals - participants of the insurance market. The tendencies of using tax preferences in purchasing insurance market products are analyzed. It was concluded that there are many disputable aspects of the application of tax preferences by organizations and individuals in Russia. It is revealed that in Russia there are no tax incentives for the development of voluntary property insurance for individuals and liability insurance for organizations, and of individual medical insurance. The direction of development and adaptation of preferences to modern conditions are determined.
\end{abstract}

Keywords: Tax Regulation of the Insurance Market, Tax Preferences for Insurance Expenses for Organizations, Tax Preferences for Individuals as Insurants, Tax Preferences for Individuals as Beneficiaries, Social Tax Deductions, Non-Taxable Income.

\section{Introduction}

In each country insurance is one of the main tools of risk management and strategic management of the economy. There are studies that show that the Russian insurance market has features related to the specificity of the population, special, in the field of life insurance, accident insurance and property insurance (Nishnianidze, O., Gaidukova, I..).

The development of the insurance market depends on the initiative of two participants: the seller of insurance services and the buyer of insurance services. The buyer in the insurance market should have several components: free financial resources to purchase insurance products, confidence in full compensation for damage. In the opinion of many Russian specialists in the field of insurance, the main problem of the insurance market in crisis times is a sharp decline in individual and organization's demand from due to lack of financial resources, distrust of insurance companies, low insurance culture level. (Ulybyna L.K., Khitrova E.M.). In the condition of a competitive insurance market, there are different states of the seller and buyer in the insurance market: the same unstable state of the insurer and the insured entails their security, and vice versa, when the insurer feels a great instability of the market - the consumer can refuse insurance. (Anwar, S., Zheng, M.) .

According to D.S. Sokolov opinion, development of insurance is based on the availability of middle class, high standard of living, as well as on stimulating demand for insurance (Sokolov D.S.). And forms of the organization of an insurance covering influence quality of the population (Kaigorodova G.N., Mustafina A.A.). The demand for insurance services depends on the policy of insurance premiums also (Alyakina D.P., Khisamova G.F.) According to forecasts, in Russia the main types of insurance are social types: unemployment insurance, from accidents and illnesses, pension insurance, student insurance, citizens traveling abroad. In this regard, the most important is the tax incentive for spending investment of legal entities and individuals in the services of the insurance market, as insurers and beneficiaries.

We agree with G.A. Nasyrova, that one more guarantee of development of formation of demand for insurance services is a conscionable and qualitative use of the enclosed financial resources (Nasyrova G.A.). For example, pension funds attracting significant investment resources and acting as institutional investors are leading players in the Theory

Problems of tax preferences for Russia are very relevant, especially from the point of view of their effectiveness. As we see it, the effectiveness of tax benefits manifests itself, first of all, not so much in reducing tax liabilities, as in the use of savings on taxes (Adigamova F.F., Orlova M.E. ). Tax regulation is recognized as one of the tools to regulate the insurance market (Galimardanova Y.M., Khafizova A.R., Salmina S.V.). A prerequisite for effective use of tax regulation tools is their compliance with the needs of economies (Sidorova, E.). We agree with the thesis that through the tax rate the state can influence the relationship between managers (employers) and employees (Stefański, J., Cichocki, W.)

Tax instruments in the field of insurance are more pronounced in the field of personal insurance. Moreover, the role of employers in these types of insurance is of key importance. The employers' proposal of social packages in labor costs allows them to attract highly qualified and sought-after specialists, as well as to increase labor productivity while maintaining quality of life and health. In particular, according to expert estimates, the bulk of sales in the 
market of voluntary medical insurance in Russia account for the corporate sector. At the end of 2015, the number of such contracts decreased by $34.7 \%$ compared to 2014. In the state of stagnation in 2015 there was also a life insurance market, the number of newly concluded contracts falls. In the field of pension insurance, the level of payments is growing, which reached $71.6 \%$ of insurance premiums (Yurgens I.Y.). The tax component is a tool to increase the interest of organizations and individuals in investing in the insurance market. They are tax preferences on indirect and direct taxes In Russia. Initially, it should be noted that insurance services are not subject to value-added tax (Article 148 of Chapter 21 of the Tax Code of the Russian Federation), which reduces their cost to the insured. In respect of policyholders, organizations and individuals, as well as beneficiaries Russian legislation provides some rights in the choice of such methods. The use of these methods is quite rigidly regulated. Methods of tax incentives can be considered from the point of view of formation of expenses (insurance fees) and income (insurance compensation) for two main taxes: profit tax and personal income tax and compulsory insurance payments (Figure 1).

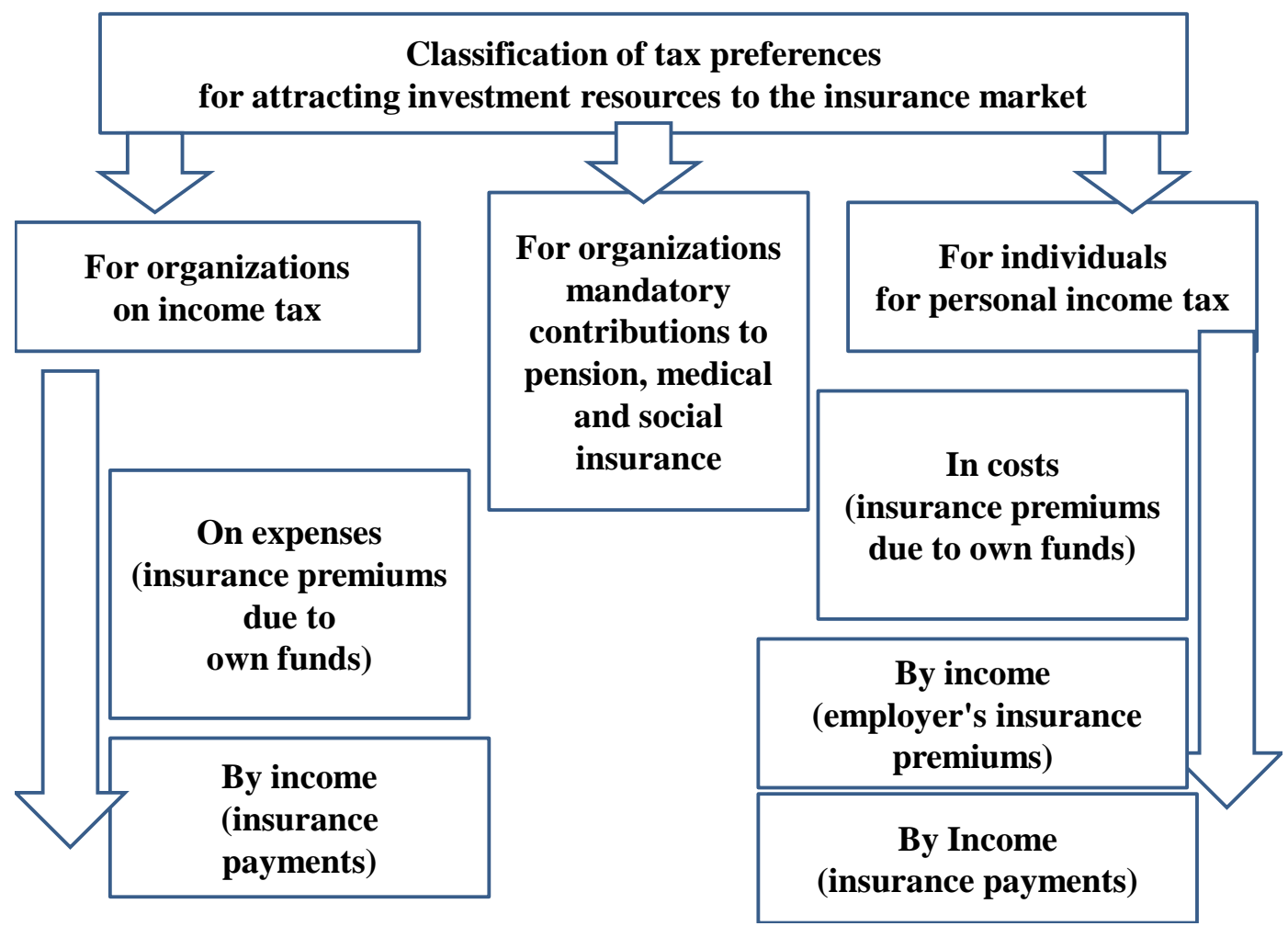

Fig.1. Classification of Tax Preferences applied in Russia to the Insurance Market

For organizations in the Russian Federation, tax preferences are provided both for insurance costs in their favor and for expenses in favor of employees. For individuals, the insurance premiums themselves serve as an object of preferences, both in their favor and in favor of third parties (close relatives), as well as insurance payments. Table 1 summarizes the tax legislation proposed by tax legislation for the participation of organizations in the insurance market as insurers.

Organizations are entitled to take into account expenses for voluntary personal insurance of employees (Article 255 of the Tax Code of the Russian Federation) and expenses for property insurance of legal entities themselves (Article 263 of the Tax Code of the Russian Federation) when forming expenses for purposes of calculating the profit tax.

Table 1: Tax Instruments for Attracting Financial Resources of Legal Entities to the Insurance Market

\begin{tabular}{|c|c|c|}
\hline $\begin{array}{c}\text { Norm of } \\
\text { the TC } \\
\text { RF }\end{array}$ & The essence of preferences \\
\hline
\end{tabular}

\section{For Personal Insurance}

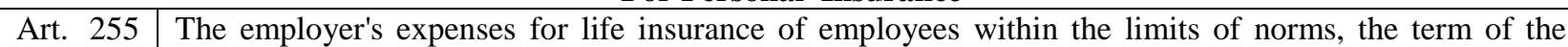
pp.16 contract is not less than 5 years, without insurance payments before the occurrence of the insurance event (no more than $12 \%$ of labor costs)

Art. 255 The employer's expenses for non-state pension provision, and voluntary pension insurance within the

pp.16 limits of the norms, the term of the contract is not less than 5 years, without insurance payments before the occurrence of the insurance event (no more than $12 \%$ of labor costs)

Art. 255 The employer's expenses for voluntary personal insurance for medical expenses within the limits of the pp.16 norms, the term of the contract is not less than 1 year (not more than $6 \%$ of labor costs) 


\begin{tabular}{|l|l|}
\hline $\begin{array}{l}\text { Art. 255 } \\
\text { pp.16 }\end{array}$ & $\begin{array}{l}\text { The employer's expenses for voluntary personal insurance, which provides for payments only in cases of } \\
\text { death and (or) damage to the health of the insured person within the limits of the norms (not more than } 15 \\
\text { TR per year per employee) }\end{array}$ \\
\hline $\begin{array}{l}\text { Ch. } 34 \\
\text { TC RF } \\
\text { Art 422, } \\
\text { Cl. 1, cl. } \\
5 \text { and } 6\end{array}$ & $\begin{array}{l}\text { Insurance premiums for compulsory pension, social and health insurance are not subject to mandatory } \\
\text { consunce for employees, voluntary personal insurance for medical expenses, voluntary personal insurance } \\
\text { contributions Under non-state pension provision agreements. }\end{array}$ \\
\hline \multicolumn{2}{|c|}{ For Property Insurance } \\
\hline $\begin{array}{l}\text { Art. 263 } \\
\text { of the TC } \\
\text { of the RF }\end{array}$ & $\begin{array}{l}\text { The costs of insurance of property (transport, cargo, inventory, fixed assets, intangible assets, unfinished } \\
\text { construction projects, crop crops, animals, SMR risks, economic and political risks of export credits) }\end{array}$ \\
\hline $\begin{array}{l}\text { Art. 263 } \\
\text { of the TC } \\
\text { of the RF }\end{array}$ & $\begin{array}{l}\text { Expenses for voluntary insurance of liability for damage or liability under the contract, if such insurance } \\
\text { is a condition for the taxpayer to carry out activities in accordance with international obligations of the } \\
\text { Russian Federation or generally accepted international requirements }\end{array}$ \\
\hline
\end{tabular}

Also as preferences it is possible to consider deducing from the taxation by compulsory insurance contributions the amount of insurance payments for compulsory insurance and voluntary personal insurance of employees (Article 422 of the Tax Code of the Russian Federation). The share of expenses of organizations - employers for voluntary insurance of employees in the total amount of expenditures in 2015 was less than $0.1 \%$, and totaled 114.5 billion rubles. In Fig. 2 shows the structure of expenses for personal insurance, stipulated by art. 255 of Chapter 25 of the Tax Code of the Russian Federation: voluntary insurance of employers-organizations for life insurance, pension insurance, medical insurance.

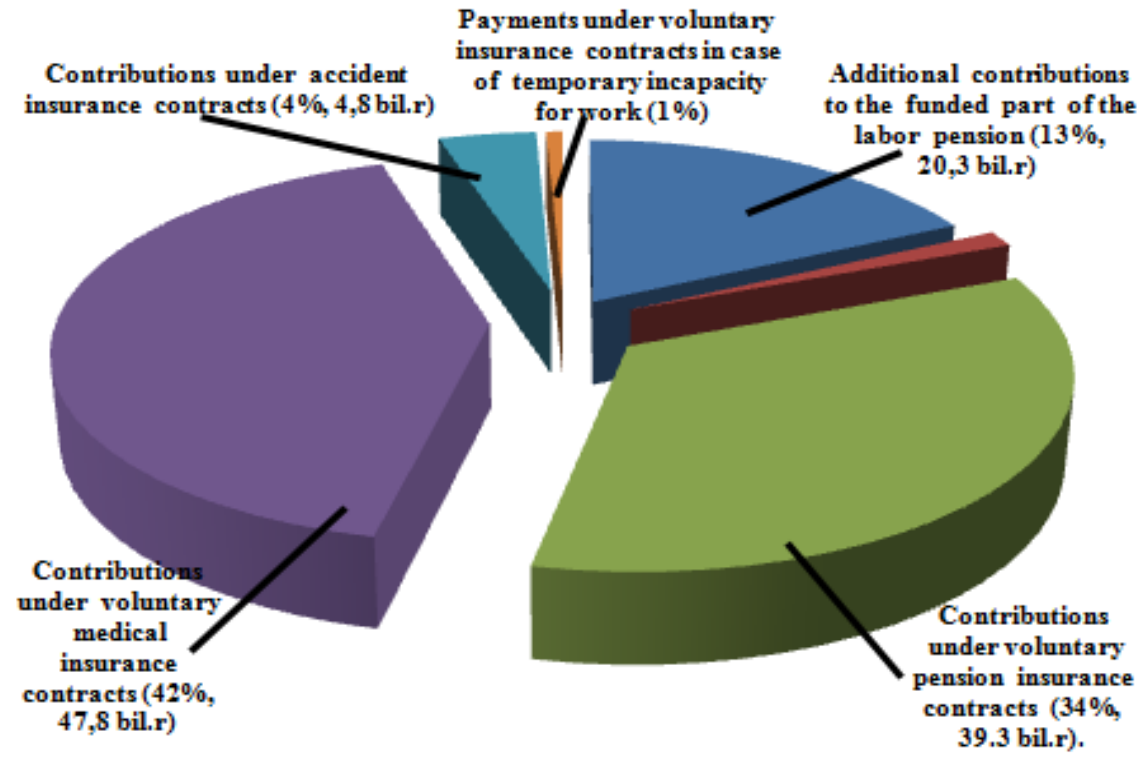

Fig.2. Structure of Expenses of Employers - Organizations for Employee Insurance in Russia in 2015 y. ${ }^{1}$

The main share in the total amount of such expenses (42\%) is occupied by the cost of concluding voluntary medical insurance contracts, which amounted to 47.8 billion rubles, followed by contributions for voluntary pension insurance - 39.3 billion rubles. Contributions to the funded part of the labor pension amounted to 20.3 billion rubles (these costs are no longer relevant for subsequent periods). An insignificant share is occupied by contributions to voluntary insurance against accidents ( 4.8 billion rubles) and life insurance (1.5 billion rubles).

World experience shows that employers' insurance premiums for health insurance are growing. So, in the USA in 2013, insurance premiums increased by $5 \%$, and premiums for family insurance - by $4 \%$. In the US, $57 \%$ of firms offer health insurance programs, $62 \%$ of employees are covered by family benefits for health insurance. Most companies (77\%) offered health programs (Claxton, G., Rae, M., Panchal, N.,

\footnotetext{
${ }^{1}$ Compiled on the basis of reporting by the Federal Tax Service. The accounts of the Federal Tax Service do not contain this information for previous periods. 
Damico, A., Whitmore, H., Bostick, N., Kenward, K.).

The development of the life insurance market has a positive impact on the economic growth of states. The level of influence varies in different countries. The positive impact of life insurance on the economy is increasing in low-income countries. And, as the researchers note, the development of the insurance market and the stock market complement each other (Chen, P.-F., Lee, C.-C., Lee, C.-F.). According to Russian researchers, life insurance is an economic tool that allows you to accumulate large amounts of money at the level of the country, regions and some insurers, as well as ensure the growth of living standards of citizens and social stability in society. At the same time, the Russian life insurance market is uneven by region: life insurance is the required financial product in Moscow, but in regions of Russia the demand for it is extremely limited. The volumes of life insurance in the regions of Russia depend significantly on the activity of the real sector of the economy, while they practically do not have a close relationship with the incomes of the population (Prokopjeva, E.L.). This once again confirms the need to expand instruments of tax regulation to attract financial resources of employers and individuals to the personal insurance market. It should be noted that for organizations the use of insurance premiums for life insurance, medical insurance, pension insurance is a tool to optimize tax and non-tax payments. Replacement of part of labor remuneration with social guarantees will allow them to be withdrawn from taxation for personal income tax and compulsory insurance contributions.

With regard to property insurance organizations, the costs of organizations for property insurance are fully recognized for tax purposes. There are no restrictions on the attribution of such costs, if the contract is in compliance with the current legislation. As noted in the analytical information, the demand for services of the property insurance market depends entirely on the policy of insurance premiums. The growth of the insurance premium reduces the demand for insurance services for property insurance. So, in 2015, in the field of cargo insurance, the growth of the insurance premium by $24.2 \%$ caused a $25 \%$ drop in sales, in the context of property insurance - a $15.7 \%$ decrease in the insurance premium entailed sales growth of $13.2 \%$ (Yurgens I. Y.).

Individuals, being insurers and beneficiaries in the insurance market, have certain preferences for both expenses (insurance premiums) and incomes (insurance reimbursements). The basic tax preferences offered to individuals are summarized in Table 2.

Table 2. Tax Instruments for Attracting Financial Resources of Individuals to the Insurance Market

\begin{tabular}{|c|c|}
\hline $\begin{array}{l}\text { Norm of the } \\
\text { TC RF }\end{array}$ & The essence of preferences \\
\hline \multicolumn{2}{|r|}{ For Personal Insurance } \\
\hline $\begin{array}{l}\text { Art. } 219 \\
\text { TC RF, } \\
\text { clause } 1 \text {, } \\
\text { subitem } 4\end{array}$ & $\begin{array}{l}\text { Expenses: Social tax deductions for expenses for voluntary pension insurance in their favor and for } \\
\text { the benefit of spouses, parents and children, including adoptive parents and adopted children, } \\
\text { grandparents and grandchildren, full-time and half-siblings, children with disabilities who are under } \\
\text { guardianship (Guardianship) }\end{array}$ \\
\hline $\begin{array}{l}\text { Art. } 219 \\
\text { TC RF, } \\
\text { clause } 1 \text {, } \\
\text { subitem } 4\end{array}$ & $\begin{array}{l}\text { Expenses: Social tax deductions for non-state pension provision expenses in their favor and for the } \\
\text { benefit of spouses, parents and children, including adoptive parents and adopted children, grandparents } \\
\text { and grandchildren, full-time and half-siblings, children with disabilities who are under guardianship } \\
\text { (Guardianship) }\end{array}$ \\
\hline $\begin{array}{l}\text { Art. } 219 \\
\text { TC RF, } \\
\text { clause } 1 \text {, } \\
\text { subitem } 4\end{array}$ & $\begin{array}{l}\text { Expenses: Social tax deductions for expenses on voluntary life insurance for a period of not less than } \\
\text { five years in their favor and in favor of spouses, parents and children, including adoptive parents and } \\
\text { adopted, grandparents and grandchildren, full-time and half-siblings, children -Invalids under } \\
\text { guardianship (guardianship) }\end{array}$ \\
\hline \multicolumn{2}{|r|}{ The general size of a social deduction can't exceed 120000 rub a year } \\
\hline $\begin{array}{l}\text { Art. } 213 \\
\text { Clause } 1 \\
\text { subitem } 1\end{array}$ & $\begin{array}{l}\text { Incomes: no payments under compulsory insurance contracts carried out in accordance with the } \\
\text { procedure established by the legislation of the Russian Federation }\end{array}$ \\
\hline $\begin{array}{l}\text { Art. } 213 \\
\text { Clause } 1 \\
\text { subitem } .2\end{array}$ & $\begin{array}{l}\text { Income: no payments under voluntary life insurance contracts } \\
\text { - if payments are related to the survival of the insured person to a certain age or term, or in the event } \\
\text { of another event; } \\
\text { - if under the terms of such a contract, insurance premiums are paid by the taxpayer; } \\
\text { - if the sums of insurance payments do not exceed the amounts paid to them by insurance premiums, } \\
\text { increased by the amount calculated by sequentially summarizing the products of insurance premiums } \\
\text { paid from the date of conclusion of the insurance contract to the end date of each year of the operation } \\
\text { of such voluntary life insurance contract (inclusive), and the acting In the corresponding year of the } \\
\text { average annual refinancing rate of the Central Bank of the Russian Federation. }\end{array}$ \\
\hline $\begin{array}{l}\text { Art. } 213 \\
\text { Clause } 1 \\
\text { subitem } .3\end{array}$ & $\begin{array}{l}\text { Incomes: no payments under voluntary personal insurance contracts providing for payment in case of } \\
\text { death, causing harm to health and (or) reimbursement of medical expenses of the insured person (with } \\
\text { the exception of payment for the cost of sanatorium vouchers) }\end{array}$ \\
\hline
\end{tabular}




\begin{tabular}{|c|l|}
\hline $\begin{array}{c}\text { Art. 213 } \\
\text { Clause 1, } \\
\text { subitem .4 }\end{array}$ & $\begin{array}{l}\text { Incomes: no payments under voluntary pension insurance agreements concluded by individuals in their } \\
\text { favor with insurance organizations are made upon the occurrence of pension grounds in accordance } \\
\text { with the legislation of the Russian Federation. }\end{array}$ \\
\hline $\begin{array}{c}\text { Art. 213.1 } \\
\text { Clause 1 }\end{array}$ & $\begin{array}{l}\text { Income: insurance contributions for compulsory pension insurance paid by organizations and other } \\
\text { employers are not assessed }\end{array}$ \\
\hline $\begin{array}{c}\text { Art. 213.1 } \\
\text { Clause 1 }\end{array}$ & $\begin{array}{l}\text { Income: the amount of pension contributions under non-government pension provisions, concluded by } \\
\text { organizations and other employers with licensed Russian non-government pension funds is not subject } \\
\text { to taxation; } \\
\text { Income: the amount of pension contributions under non-state pension provision agreements concluded } \\
\text { by individuals with licensed Russian non-government pension funds is not assessed in favor of other } \\
\text { persons }\end{array}$ \\
\hline $\begin{array}{c}\text { Art. 213.1 } \\
\text { Clause 1 }\end{array}$ & $\begin{array}{l}\text { Income: The amount of pensions paid under non-state pension provision agreements that are concluded } \\
\text { by individuals with licensed Russian non-government pension funds is not taxed in their favor }\end{array}$ \\
\hline $\begin{array}{c}\text { Art. 213.1 } \\
\text { Clause 1 } 1\end{array}$ & $\begin{array}{l}\text { Income: The amount of pensions to individuals who are paid under non-state pension provision } \\
\text { agreements, concluded by organizations and other employers with licensed Russian non-state pension } \\
\text { funds, pension contributions for which before January 1, 2005 were paid by the employer to these } \\
\text { funds with withholding and payment of tax On income of individuals }\end{array}$ \\
\hline \multicolumn{2}{|c|}{ For Property Insurance } \\
\hline Art. 213 & $\begin{array}{l}\text { Incomes: insurance premiums paid by the lessee for OSAGO and CASCO are not levied on leasing } \\
\text { vehicles by individuals }\end{array}$ \\
\hline $\begin{array}{c}\text { Art. 213.1 } \\
\text { Clause 4 }\end{array}$ & $\begin{array}{l}\text { Incomes: insurance claims for property insurance are not subject to the condition that the amount of } \\
\text { compensation does not exceed the damage (costs of repairing the property) }\end{array}$ \\
\hline
\end{tabular}

The main tax preferences for individuals is the possibility of applying social tax deductions for the implementation of expenses for certain types of personal insurance, as provided in Art. 219 of the Tax Code: insurance premiums for voluntary pension insurance, pensions, life insurance. Figure 3 shows the dynamics of the application of social tax deductions for voluntary personal insurance according to the reporting of the Federal Tax Service of Russia. The figures show that the total amount of social tax deductions has an active growth dynamics. For the period from 2009 to 2014, the amount of social tax deductions increased by 5.2 billion rubles, reached
10.2 billion rubles, which was more than $100 \%$ of the 2009 level. And according to the Federal Tax Service data, in 2014, $84.5 \%$ fall on insurance premiums from employers - tax agents. It can be seen that the consequences of the economic crisis of 2014 affected the activity of individuals, which resulted in a reduction in social tax deductions for non-state pension insurance and collateral. In 2014, the amount of tax deductions for pension insurance and collateral decreased to the level of 2009. In 2009, the share of tax deductions for pension insurance was $88.6 \%$, and in 2014 their share fell to $55 \%$.

Fig. 3. Dynamics of Social Deductions for Expenditures on Pension, Medical Insurance Life Insurance, declared by Individuals and Applied by Tax Agents ${ }^{2}$

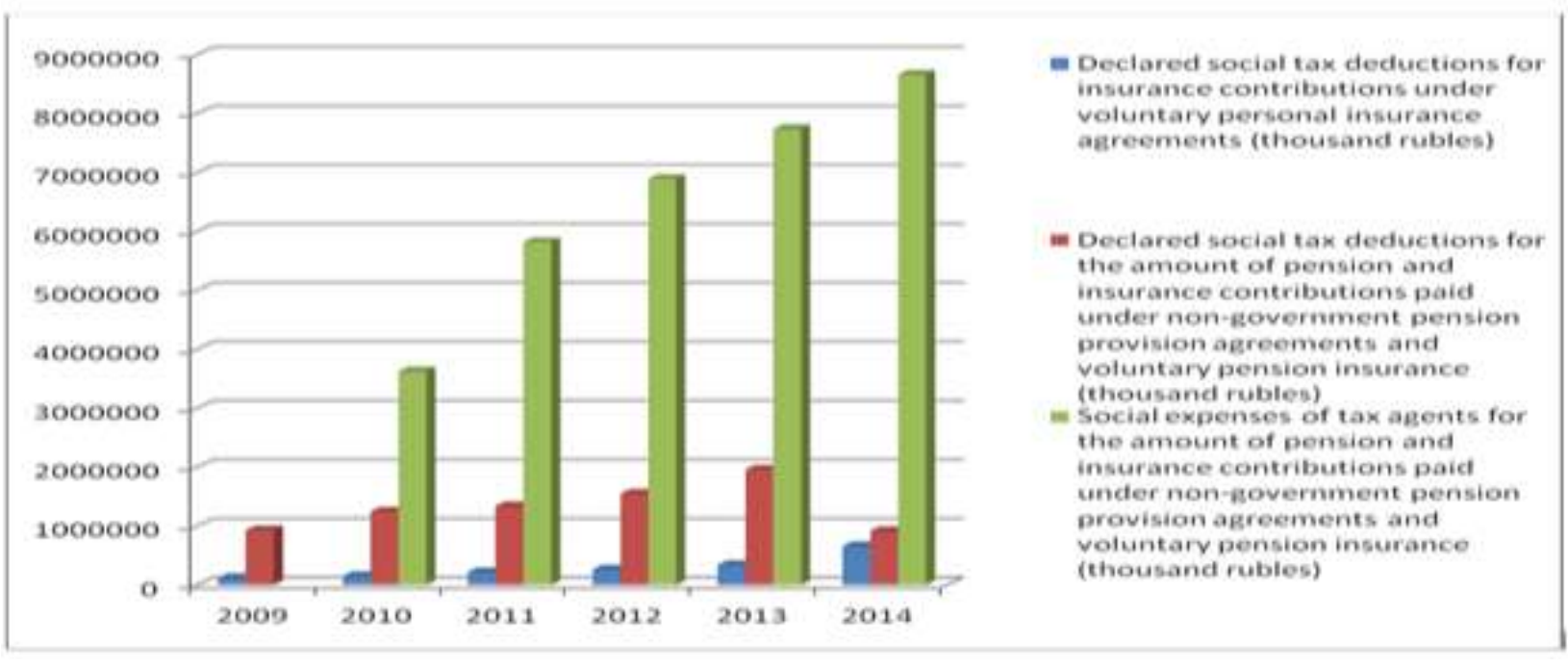

Results

\footnotetext{
${ }^{2}$ Compiled on the basis of the accounts of the Federal Tax Service of Russia, taking into account the comparability of information 
Analysis of the use of tax preferences in Russia showed that the crisis of 2013 affected the investment decisions of individuals. The investment activity of individuals in the sphere of personal insurance is reduced, the application of tax deductions for pension insurance is reduced. This proves a decrease in the interest of citizens in this segment of the insurance market. At the same time, there is an increase in employers' personal insurance expenses. First of all, it makes it possible to reduce the tax burden on the payroll for the income tax and payments for compulsory social insurance. The tax practice of employing employers on the voluntary insurance of employees within the wage fund showed a number of controversial issues in this area. Tax authorities, controlling the validity of expenses, often do not recognize them as such. One of the main requirements is the need to define these types of expenditures in collective and labor contracts. We believe that the " stretching" of expenses in the form of insurance premiums for the duration of the insurance contract, reduces the demand for insurance services. Also, the tax legislation does not determine the specifics of the formation of costs with the further termination of the contract on the part of the beneficiary and the receipt of redemption amounts, although in economic terms these costs should be restored.

In addition, there are many other controversial issues: in the contract of personal insurance, the insured must be specified by the employer, and not by the employees; In the contract of personal insurance for the provision of medical expenses, the replacement of the insured persons may be the reason for the restoration of such expenses; It is disputable to take into account in the costs of insurance premiums while reducing the terms of contracts. Another problematic aspect is the dilemma of the presence or absence of a tax base for personal income tax for beneficiaries and a basis for calculating compulsory social contributions when paying insurance premiums in excess of the limits established by the tax legislation. Controversial is the issue of accounting for insurance premiums for employees who create, erect, reconstruct fixed assets and create intangible assets (contributions are included in other expenses or expenses for the creation and construction of fixed assets and intangible assets). All these factors of the tax risk of applying tax preferences reduce the demand for insurance services.

As for voluntary medical insurance, the tax deduction for individuals in the tax legislation of Russia on insurance premiums is not provided. At the same time, there is a social deduction for medical services. We believe that the lack of an opportunity to reduce the tax base for personal income tax on insurance premiums in the sphere of voluntary medical insurance is constrained by the demand for similar insurance services. In our opinion, from the point of view of tax expenditures, it is more advantageous to apply as a tax deduction not all expenses for medical services, but only an insurance premium. It is interesting that when comparing Rosstat's statistical reports on the dynamics of insurance premiums and the reporting data of the Federal Tax Service, it was found out that the share of declared insurance premiums as tax deductions of individuals and organizational expenses amounted to only $3.4 \%$ in 2009 , and in $2014-2.7 \%$ (figure 4 ).

Fig. 4 Comparison of the Dynamics of Insurance Premiums by Types of Personal Insurance According to the Federal State Statistics Service and According to the Federal Tax Service of the Russian Federation (Million Rubles)

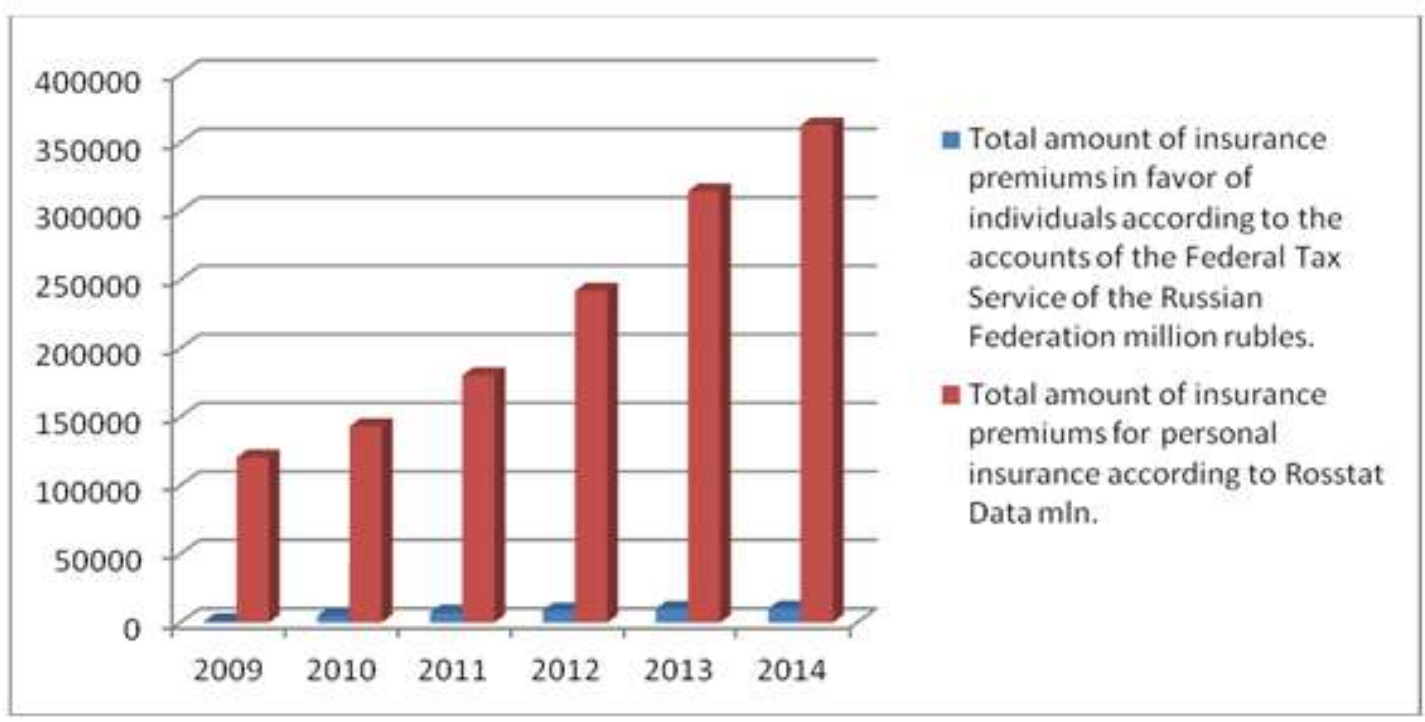

\footnotetext{
${ }^{3}$ Compiled on the basis of data from the Federal State Statistics Service and the Federal Tax Service of Russia 
insurance as accident insurance and health insurance are not included in the system of social tax deductions within the tax on personal income. According to the Federal State Statistics Service, insurance premiums for insurance against accidents and medical insurance in 2015 amounted to more than 66\% (see Figure 5). Thus, a significant volume of insurance premiums is not covered by tax preferences for personal income tax. Such types of insurance as accident insurance and health insurance are not included in the system of social tax deductions within the tax on personal income.

Among the many problems of applying tax preferences for individuals in the framework of medical insurance, one can single out the one that is related to insurance reimbursements under voluntary medical insurance contracts initiated by the employer. This applies to insurance payments in the form of services for sanatorium treatment.

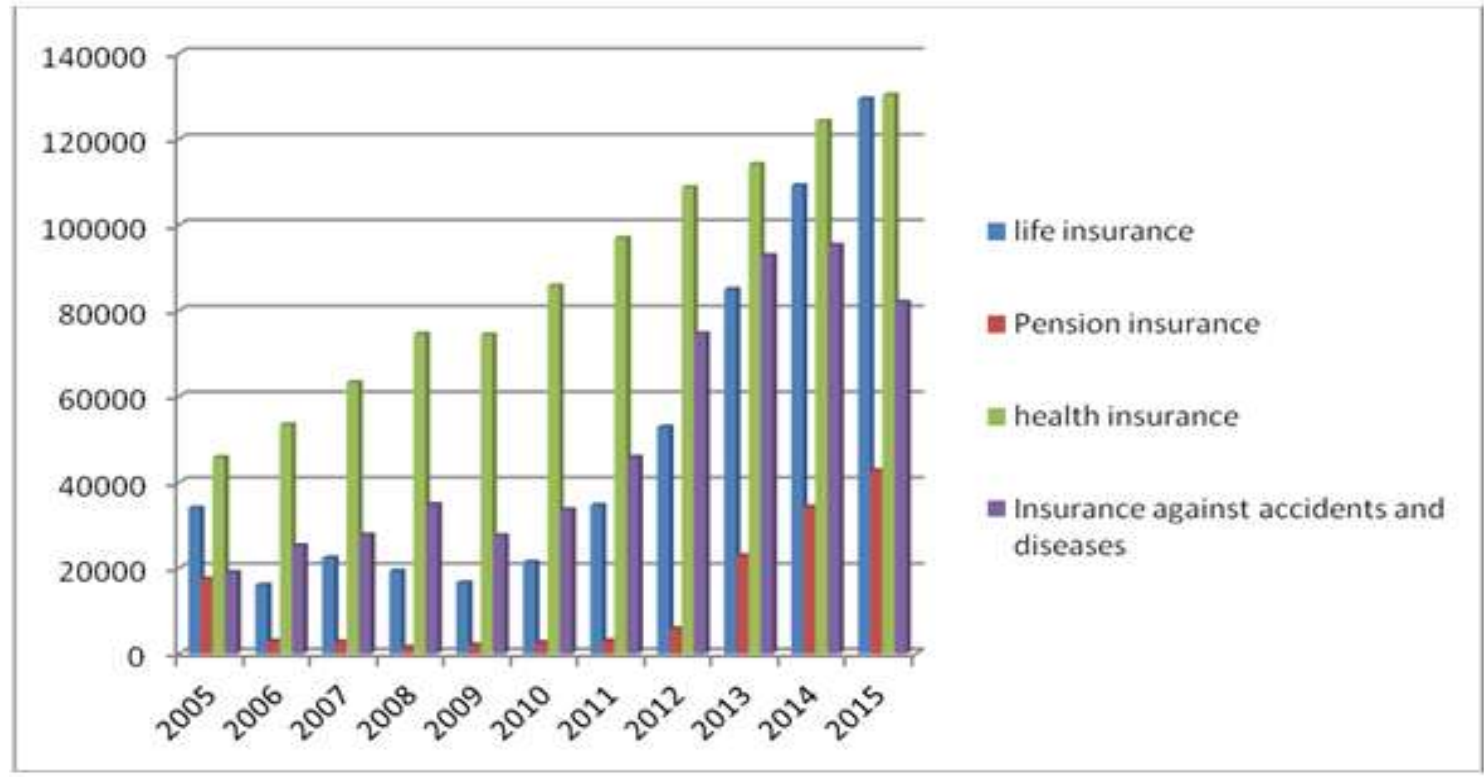

Fig. 5. Dynamics and Structure of Insurance Premiums by Types of Personal Insurance for the Period from 2005 to $2015 .^{4}$

The tax authorities insist that these payments are incomes of an individual. But there is a position of courts on which such services are not recognized as income. It should be noted that the employer's expenses for resort and sanatorium treatment in Russia are not subject to income tax. The main problem in property insurance of organizations is attribution of insurance premiums for liability insurance to organizations. In article 263 of the Tax Code of the Russian Federation, the criteria for these expenses have been determined. You cannot attribute expenses to any voluntary types of liability insurance, except those provided for in international treaties. In this list it is possible to allocate such expenses, as: expenses on insurance of responsibility for causing of harm at operation of dangerous industrial object (there are positive court decisions); voluntary professional liability insurance; expenses for insurance of professional risks (appraisers, auditors and others); expenses for insurance of business risks (losses from idle time); expenses for liability insurance (for state and non-government contracts). It should also be noted that there are no tax preferences for individuals on property types of insurance. According to experts' estimates, property insurance of individuals is the most

\footnotetext{
${ }^{4}$ Compiled on the basis of Rosstat RF data.

interesting from the perspective of development (Yurgens I.Y.).

\section{Discussion}

Thus, the development of the insurance market in Russia depends on such factors as:

- The specificity of the population of the region;

- The level of economic development of regions;

- The volume of free funds of insurers, and the presence of middle class;

- The credibility of the insurance companies;

- Sense of stability of the insurance market for insurers:

- Conscientious and quality use of financial investments by insurers;

- The General level of insurance culture of individuals and employers.

It is established that the consequence of economic crisis for Russia is the reduction of the demand of individuals and organizations for insurance services. Investment activity of individuals in the field of personal insurance reduced tax deductions on pension insurance is shrinking. The main reason for such trend is the reduction in real income of individuals and organizations.

Determined that Russia will be developed more actively the types of social insurance: unemployment 
insurance, accident and illness, pension insurance, insurance students, citizens traveling abroad.

Crucial tax incentives for investments of legal and natural persons in these services the insurance market as policyholders and beneficiaries.

Rising costs of employers on private insurance professionals. This mechanism is used by employers to reduce the tax burden on payroll tax revenues and payments for compulsory social insurance.

A comparison of the data of Rosstat and Federal tax service of Russia for insurance premiums (costs) showed that a substantial volume of insurance premiums on personal insurance not covered by tax preferences under the tax to incomes of physical persons.

Development of voluntary pension insurance is hampered by the absence of preferences (exclusion from taxation) on the payment of pensions under the agreements concluded by employers.

(Thus, development of the insurance market in Russia depends on such factors as: - specifics of the population of the region; - level of development of economy of regions; - volume of free monetary resources of insurers and presence of the middle class; - trust to insurance companies; - sense of stability of the insurance market for insurers; - conscientious and high-quality use of financial investments by insurers; - general level of insurance culture of natural persons and employers. It is established that a consequence of an economic crisis for Russia is decrease in demand of natural persons and the organizations for insurance services. The investment activity of natural persons in the sphere of personal insurance decreases, application of tax deductions on pension insurance is reduced. Such tendency reduction of real income of natural persons and the organizations is the main reason. It is defined that in Russia types of social insurance will develop most actively: insurance on unemployment, from accidents and diseases, pension insurance, insurance of pupils, the citizens who are going abroad. Tax incentives of investments of legal entities and individuals in the above-named services of the insurance market as insurers and beneficiaries are essential.

Growth of expenses of employers on personal insurance of workers is observed. This mechanism is used by employers for decrease in tax burden of the salary fund on a tax on income and payments on obligatory social insurance. Comparison of data of Rosstat and Federal Tax Service of the Russian Federation on insurance premiums (expenses) has shown that the considerable volume of insurance premiums on personal insurance isn't captured by tax preferences on an income tax. The lack of preferences (an exception from under the taxation) on payments of pensions under the contracts signed by employers interferes with development of voluntary pension insurance.)

\section{Conclusions}

Analysis of the state of the Russian insurance market and review of tax preferences proposed by the Russian tax legislation for legal entities and individuals, as well as the procedure for their application with the aim of regulating the development of the insurance market and its withdrawal from stagnation allows us to recommend the following aspects of their development:

- to expand the ability of taxpayers-insurers, especially organizations, to actively use liability insurance for both proprietary and professional liability, to allow insurance premiums for this type of insurance to be charged to expenses for purposes of calculating the profit tax;

- introduce an additional social tax deduction for individuals for voluntary medical insurance in their favor in favor of spouses, children, parents;

- Introduce an investment tax deduction for the costs of individuals for personal property insurance.

\section{Acknowledgements}

The work is performed according to the Russian Government Program of Competitive Growth of Kazan Federal University.

\section{References}

1. Adigamova F.F., Orlova M.E. Academic and practical aspects of tax preferences // Innovation development of economy vol. 3 (33) II - 2016, 4954/

2. Alyakina D.P., Khisamova G.F. Methodology for rating of insurance portfolio // Mediterranean Journal of Social Sciences vol. 5 № 24, November 2014, pp. 137-140.

3. Anwar, S., Zheng, M. Competitive insurance market in the presence of ambiguity (Article) Insurance // Mathematics and Economics Volume 50, Issue 1, January 2012, Pages 79-84.

4. Chen, P.-F., Lee, C.-C., Lee, C.-F. How does the development of the life insurance market affect economic growth? Some international evidence (Article) // Journal of International Development Volume 24, Issue 7, October 2012, Pages 865893.

5. Claxton, G., Rae, M., Panchal, N., Damico, A., Whitmore, H., Bostick, N.d, Kenward, K. Health benefits in 2013: Moderate premium increases in employer-sponsored plans (Article) // Health Affairs Volume 32, Issue 9, 2013, Pages 16671676.

6. Data on the forms of statistical tax reporting of the Federal Tax Service of

Russiahttps://www.nalog.ru/rn16/related_activiti es/statistics_and analytics/forms/

7. Rosstat's data on insurance premiums http://www.gks.ru/wps/wcm/connect/rosstat _main/rosstat/ru/statistics/finance/\#

8. Galimardanova Y. M., Khafizova A.R., Salmina S.V. The necessity for taxable capacity assessment for the segments of the insurance 
market // Mediterranean Journal of Social Sciences vol. 5 № 24, November 2014, pp. 407411.

9. Kaigorodova G.N., Mustafina A.A.The influence of forms of insurance coverage organization on population's life quality // Mediterranean Journal of Social Sciences vol. 5 № 24, November 2014, pp. 118-123.

10. Kuznetsova, N.P., Pisarenko, Z.V. Financial convergence analysis: Implication for insurance and pension markets (Article) // Business: Theory and Practice Volume 17, Issue 2, 20 June 2016, Pages 89-100.

11. The Tax Code of the Russian Federation (part two) "of 05.08.2000 N 117-FZ (as amended on December 28, 2016).

12. Nasyrova G.A. Models of state regulation of insurance activity / / Vestnik FA, 2003 (4), p. 3849.

13. Nishnianidze, O, Gaidukova, I.. Impact of citizens' phenomenological risks assessment on the development of voluntary insurance market (Article) // Economic Annals-XXI Volume 157, Issue 3-4, 12 May 2016, Pages 72-74.

14. Sidorova, E. Improvement the methods of tax regulation mechanism effectiveness assessment in the Russian Federation (Article) // Economic Annals-XXI Volume 155, Issue 11-12, 2015 , Pages 47-50.

15. Stefański, J., Cichocki, W. Tax regulation design as a strategy selection in a system with conflicting goals (Article) // Annual Review in Automatic Programming Volume 12, Issue PART 2, 1985, Pages 155-159.

16. Sokolov D.S. The main priorities of state regulation of the insurance market in crisis and post-crisis period Bulletin of TSU, Issue 10 (78), 2009, p. 59-63.

17. Ulybyna L.K., Methodological aspects of institutional transformation of the insurance market in the conditions of financial globalization - Bulletin of the Adyghe State, Series of Economics, 2013, №3 (127).

18. . Khitrova E.M. On the issue of stimulating demand for insurance services / Izvestiya IGEA, 2012, №6 (86), p. 27-30.

19. Yurgens I.Y Insurance market: results 2015, forecasts, main trends, http://www.insurinfo.ru/analysis/1083/. 